\title{
U-Pb (Zircon) Ages of Metavolcanic Rocks From the Itaiacoca Group: Tectonic Implications
}

\author{
O swaldo Siga Jr. ${ }^{1}$ (osigajr@usp.br), Miguel Angelo Stipp Basei ${ }^{1}$, Kei Sato ${ }^{2}$, Hélcio José dos Prazeres Filho ${ }^{3}$, \\ Leonardo Fadel Cury³, Werner Weber ${ }^{3}$, Cláudia Regina Passarelli², O ssama Mohamed Harara ${ }^{3}$, \\ José Manoel dos Reis Neto ${ }^{4}$ \\ ${ }^{1}$ Departamento de Mineralogia e Geotectônica - Instituto de G eociências - USP \\ R. do Lago 562, CEP 05508-080, São Paulo, SP, BRA \\ ${ }^{2}$ Centro de Pesquisas G eocronológicas - Instituto de Geociências - USP, São Paulo, SP, BRA \\ ${ }^{3}$ Programa de Pós-Graduação em Geoquímica e Geotectônica - Instituto de G eociências - USP, São Paulo, SP, BRA \\ ${ }^{4}$ Setor de Ciências da Terra - Departamento de Geologia - UFPR, Curitiba, PR, BRA
}

Keywords: U-Pb zircon, metavolcano-sedimentary sequence, tectonic evolution.

\begin{abstract}
The main aim of this work is to present and discuss the U-Pb ages obtained for zircon grains from metavolcanic rocks of the Itaiacoca Group. The Itaiacoca Group is a metavolcano-sedimentary sequence, which occurs as a narrow belt between the Cunhaporanga granitic batholith to the northwest and the Itapirapuã shear zone to the south and southwest, which separates the sequence from the Três Córregos granite batholith and metasedimentary rocks of the Açungui Group. Geological studies of the southern part of the Itaiacoca belt led to the recognition of three units, represented (from base to top) by metawackes with an important volcanic component, metacarbonate, and metapelitic and metapsammitic rocks. The U-Pb geochronological analyses of zircon grains from two outcrops of metavolcanic rocks yield ages of $628 \pm 18 \mathrm{Ma}$ (SHRIMP) and $636 \pm 30 \mathrm{Ma}$ (conventional multigrain analyses). These ages are quite close to the metamorphic event recorded in the Itaiacoca Group (628 - 610 Ma), suggesting a short interval between the formation of these rocks and closure of the basin. Furthermore, this volcanism is very close to the age of formation of the Três Córregos (630 Ma) and Cunhaporanga (590 Ma) granitic batholiths, admitted as associated with a probable magmatic arc. Such an isotopic pattern characterizes a Neoproterozoic tectonic scenario involving volcanism, metamorphism and granitic plutonism, interpreted here as the final stages in the evolution of the Itaiacoca Basin.
\end{abstract}

Palavras-chave: U-Pb (zircões), seqüências metavulcano-sedimentares, evolução tectônica.

\section{RESUMO}

O objetivo principal deste trabalho é apresentar e discutir as idades geocronológicas U-Pb, em zircões de rochas metavulcânicas pertencentes ao Grupo Itaiacoca. Este é representado por uma seqüência metavulcano-sedimentar, que ocorre como uma faixa relativamente estreita, limitada a norte pelo Batólito Granítico Cunhaporanga, sendo balizada a sul, através da Zona de Cisalhamento Itapirapuã, pelo Batólito Granítico Três Córregos e pelos metassedimentos do Grupo Açungui. Os estudos geológicos efetuados na porção sul da Faixa Itaiacoca permitiram reconhecer três unidades geológicas maiores, representadas, da base para o topo, por metarcóseos (com importante contribuição vulcânica-vulcanoclástica), rochas metacarbonáticas e rochas metapelíticas-metapsamíticas. Análises geocronológicas U-Pb realizadas em zircões de dois afloramentos de rochas metavulcânicas, forneceram idades de $628 \pm 18 \mathrm{Ma}$ (SHRIMP) e $636 \pm 30 \mathrm{Ma}$ (convencional). O metamorfismo dessas rochas parece ter ocorrido em épocas bastante próximas (628 - 610 Ma) à cristalização dos zircões, sugerindo curto intervalo de tempo entre o vulcanismo estudado e os episódios de fechamento da bacia. Não obstante, as idades obtidas também se aproximam da época de formação dos batólitos graníticos Três Córregos (630 Ma) e Cunhaporanga (590 Ma), admitidos como prováveis arcos magmáticos. Tal padrão isotópico caracteriza um cenário tectônico Neoproterozóico envolvendo vulcanismo, metamorfismo e plutonismo granítico, interpretados como relativos aos estágios finais da evolução da Bacia Itaiacoca. 


\section{IN TRO DUCTION}

The Itaiacoca Group is a metavolcanoclastic sequence occupying a narrow, NE-SW oriented belt between the Cunhaporanga (NW) and Três Córregos (SE) granitic batholiths in eastern Paraná State, Southeast Brazil. Here we discuss the age pattern revealed by SHRIMP and conventional $\mathrm{U}-\mathrm{Pb}$ dating of zircon from metavolcanic rocks of this Group. We use current views on tectonic positioning, lithostratigraphic characteristics, and previously obtained ages to discuss the possible geological scenarios, which were associated with the deposition and subsequent evolution of the belt (Figure 1).

The interpretation of the tectonic position of Precambrian basins - rifted continental margin, continental rift back arc, fore arc, intra-arc, interarc - is often not an easy task since the some of the essential features may not always be evident. Furthermore, it is usually necessary to allow for the profound transformations which occur during the evolution from the original depositional environment through subduction and collision processes with accompanying deformation, development of shear zone systems, and intrusion by granitic plutons. Finally, some of the essential geological records may be missing.

\section{GEOLOGICAL FEATURES}

The bibliography on the Precambrian units of eastern Paraná and southeastern São Paulo is quite extensive, including more than a hundred publications and reports. The earlier works were dedicated to geological reconnaissance, and separated the Crystalline Basement Complex from the metasedimentary and metavolcanosedimentary sequences of the Açungui Group.

Almeida (1956) studied the region around Itaiacoca and the Serra das Antas, the area of the present study. He proposed that a packet of dolomitic marble, quartzite, phyllite and metabasic rocks be separated as the Itaiacoca Formation. On the basis of the similarity of rock types and fossil content (collenia itapevensis sp.), he correlated this formation with the Capirú Formation found south of the Lancinha shear zone (Figure 1). His proposal was supported by Bigarella and Salamuni (1956).

In attempts to define and interpret the Açungui Group in Paraná and the Apiaí fold belt in Paraná and São Paulo, many authors considered that the different metavolcanosedimentary sequences were deposited synchronically in separate basins. There was, however, disagreement about the ages of these basins, whether they were formed in both the Meso- and the Neo-proterozoic, or whether they were restricted to the Neoproterozoic. The difficulties in establishing stratigraphic columns and tectonic relationships for the metavolcanosedimentary terrains are shown by the numerous, different proposals. Fassbinder (1996) found about forty suggestions, some of which are totally discrepant.

The many specialized studies of topics such as sedimentary environments, magmatism, metamorphism and structural characteristics, tectonic compartments and geochronology (Marini et al., 1967; Fairchild, 1977; Hasui et al., 1975; Soares, 1987; Campanha et al., 1987; Biondi, 1989; Fiori, 1990, 1992; Basei et al., 1992; Reis Neto, 1994; Soares \& Rostirolla, 1997; Campanha \& Sadowski, 1999; Campos Neto, 2000, Basei et al., 2002; Weber et al.; 2002; Cury et al., 2002) contributed to define and interpret the Apiaí Fold Belt in Paraná and São Paulo states.

The subdivision of the Itaiacoca Formation or Group into different rock units on the basis of lithological, stratigraphical and sedimentological criteria was undertakern by Chiodi Filho (1984), IPT (1985), Trein et al. (1985), Theodorovicz \& Câmara (1988) Souza (1990) and Reis Neto (1994). Souza (1990) adopted the denomination Itaiacoca Group, following the previous suggestions of Hasui et al. (1984) and IPT (1985). He defined four lithostratigraphic units or formations which were later adapted, with slight modifications, by Reis Neto (1994).

In the present study which has an essentially geochronological approach, we prefer to treat this region (Apiaí Fold Belt) as a series of five large geographical compartments separated by important lineaments. These compartments were informally named Bocaiúva do Sul, Rio Ribeira, Guapiara, Ribeirão Branco and Campina dos Veados, and have as their infrastructure the Atuba Complex, composed of granite-gneisses and migmatites, which is located to the Southeast (Siga Jr. et al., 1995). The Campina dos Veados Compartment includes the metavolcanosedimentary sequences of the Itaiacoca Group and the Cunhaporanga granite batholith (Fuck et al., 1967, 1971; Prazeres Filho, 2000, Prazeres Filho et al., 2001).

The geological information used here was obtained during geological mapping of the southern part of the Itaiacoca belt between Abapã and Socavão, PR undertaken by members of the IGc-USP in 1997 (Prazeres Filho et al., 1998; Siga Jr et al., 2001; Figures 3 and 4). In this area, three main units are recognized, from base to top: metawackes with an important volcanic contribution; metacarbonate and metapelitic - metapsammitic rocks. Regional metamorphism is in the chlorite to biotite zones of the greenschist facies (Table 1). This succession is similar to that described by Souza (1990) and Reis Neto (1994) who also considered that the Água Clara Formation (SE of Itapirapuã Shear Zone), usually con- 
Figure 1. Geological sketch map showing the main geological units and tectonic subdivisions in eastern Paraná and southern São Paulo.

1 - Quaternary cover; 2 - Paraná Basin; 3 - foreland basins \{Castro (NW) and Camarinha (SW) Groups\}; Campina dos Veados Compartment: 7 - Cunhaporanga batholith [600 - $590 \mathrm{Ma}$ ], 11 - Itaiacoca Group; Ribeirão Branco Compartment: 8 - Três Córregos batholith and granitic massifs associated [630-600 Ma], 10 - Água Clara sequence [c.1450 Ma];Guapiara Compartment: 12 - Lajeado and Antinha sequences [Neoprot.?]; Rio Ribeira Compartment: 9 - Votuverava sequence [c.1450 Ma], 14 - Perau and Betara sequences [1450 Ma], 15 - deformed alkaline [1750 Ma] and calc-alkaline granitoids [2100 Ma], 6 - syn to post-colisional granitoids [590-570Ma], 4 - Tunas syenite [85 Ma]; Bocaiuva Compartment: 13 - Capirú sequence; Atuba Compartment: 16 - Atuba gneissmigmatite complex, $\mathbf{5}$ - alkaline to peralkaline granitoids of Serra do Mar suite (after Campanha, 1991; Basei et al., 1992; Siga Jr, 1995; Campos Neto, 2000).
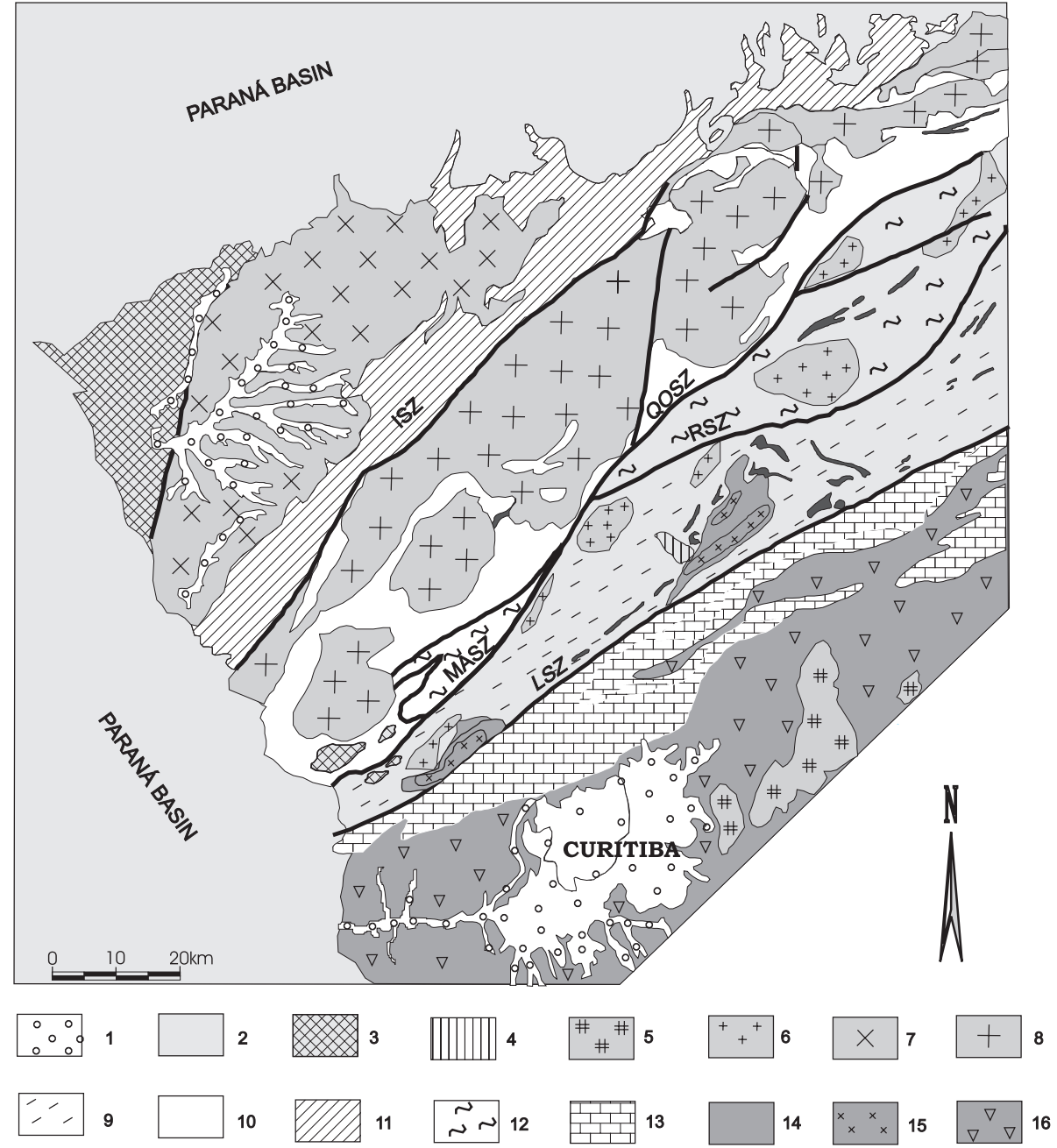

Metabasic rocks / Anphibolites TECTONIC COMPARTIMENTATION

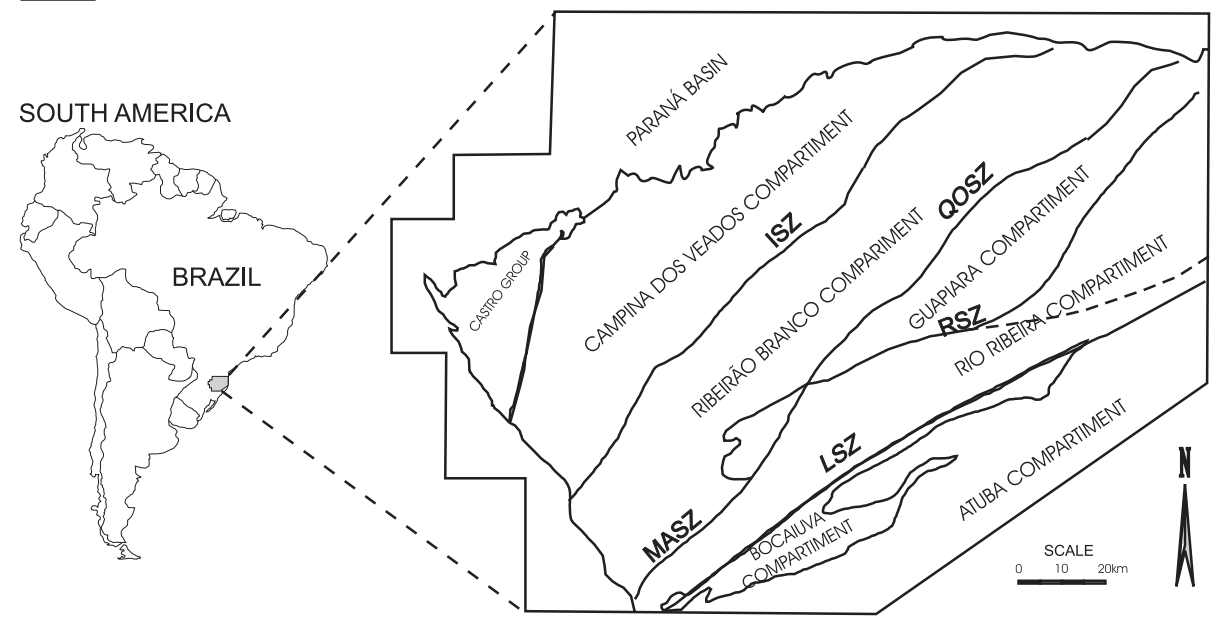

ISZ = ITAPIRAPUÃ SHEAR ZONE

QOSZ = QUARENTA OITAVOS SHEAR ZONE

RSZ = RIBEIRA SHEAR ZONE 
Table 1. Metamorphic features and mineralogic association of Itaiacoca group rocks.

\begin{tabular}{|c|c|c|c|c|}
\hline \multicolumn{3}{|c|}{ Regional Metamorphism } & \multirow{2}{*}{ Contact Metamorphism } & \multirow{2}{*}{$\begin{array}{c}\text { Dynamic } \\
\text { Metamorphism }\end{array}$} \\
\hline Unit & Conditions & Paragenesis & & \\
\hline $\begin{array}{l}\text { Itaiacoca } \\
\text { Group }\end{array}$ & $\begin{array}{c}\text { Green-Schist } \\
\text { Facies } \\
\text { (CloriteZone) }\end{array}$ & $\begin{array}{l}\text { Qz+Fk+Se } \\
\text { Qz+Se } \\
\text { Bio(?)+Qz+Cl } \\
\text { Qz+Cl } \pm \text { Opa } \\
\mathrm{Cl}+\mathrm{Se}+\mathrm{Qz} \\
\mathrm{Cc}+\mathrm{Dol} \pm \mathrm{Qz} \\
\mathrm{Dol}+\mathrm{Cc} \\
\mathrm{Se}+\mathrm{Qz} \pm \mathrm{Grf}\end{array}$ & $\begin{array}{l}\text { - } \text { silicification associated } \\
\text { with Cunhaporanga } \\
\text { Granitic Complex; } \\
\text { - Adz, Mo } \pm \text { Gar in } \\
\text { metapelites; } \\
\text { - Tlc } \pm \text { Tr in metadolomites. }\end{array}$ & $\begin{array}{l}\text { cataclasites, } \\
\text { mylonites, } \\
\text { silicification. } \\
\text { (Uirapuru Shear } \\
\text { Zone and } \\
\text { Campina do } \\
\text { Estepe Shear } \\
\text { Zone) }\end{array}$ \\
\hline
\end{tabular}

Act - actinolite; Adz - andaluzite; Bio - biotite; Cc - calcite; Cl - chlorite; Dol - dolomite; FK - potassic feldspar; Gar - garnet; Grf - graphite; Mu - muscovite; Opa - opaques; Qz - quartz; Se - sericite; Tlc - talc; Tr - tremolite.

sidered to be part of the Açungui Group, forms part of the Itaiacoca Group.

In the basal unit, metamorphosed feldspathic sandstones predominate, and contain interbedded metavolcanic and metavolcanoclastic rocks. Graded and cross beddings are preserved in the metasandstones, which are immature, rich in quartz and microcline clasts, suggesting that the source area was granitic. The clasts are set in a fine-grained matrix composed of clay minerals, sericite and chlorite. The metavolcanic rocks form flows of variable thickness interbedded with metapsammites. Thin levels of pale green phyllites (volcanic ash beds?), and other possible metapyroclastic rocks (?) are also observed. The rocks are usually highly vesicular or rich in amygdales (Trein et al., 1985; Reis Neto, 1994), which were stretched during deformation (Photos 1 and 2). The rocks are often sanidine-rich,

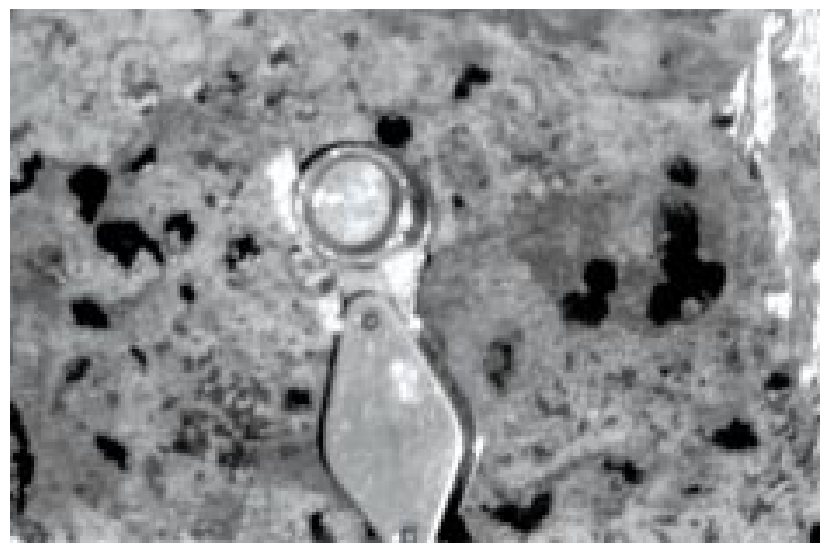

Photo 1 . Vesicles in metavolcanic rocks. and also contain devitrified material. We identify these rocks as trachytes, which according to Reis Neto (1994), are very rich in $\mathrm{K}_{2} \mathrm{O}(6-12 \%)$ and other LILE.

Dolomitic marbles interbedded with impure marbles (calcic phyllites and carbonate-bearing phyllites) predominate in the middle unit. Wavy, lenticular, climbing and cross bedding structures are preserved, as are pisoliths and oolites. Banks of columnar stromatolites are associated with algal mats (Photo 3). The marbles host levels of pale green chlorite-sericite phyllites, which may be former volcanic ashes, and metatholeiites with geochemical characteristics of extensional environments (Reis Neto, 1994). In the proximity of the Cunhaporanga batholith, these rocks are transformed into contact metamorphic assemblages rich in talc and tremolite.

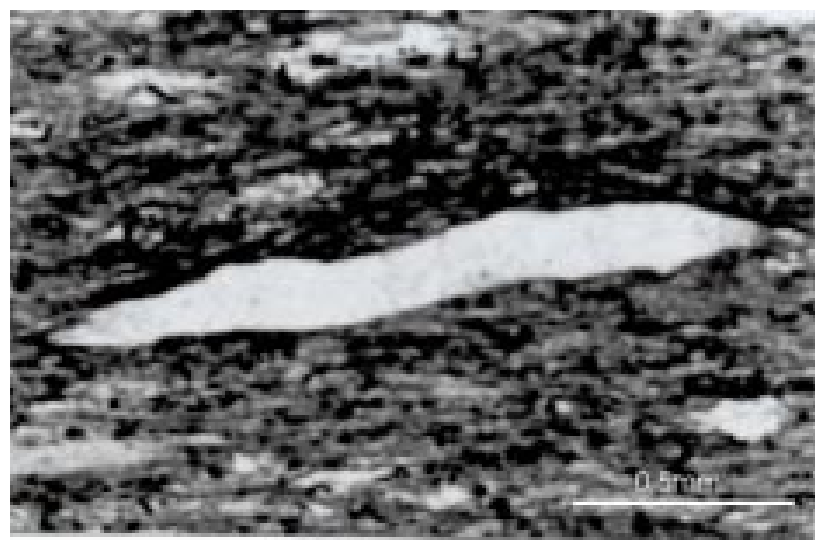

Photo 2. Microphotograph of stretched amygdales containing quart parallel to the $\mathrm{S}_{1}$ foliation; crossed polarizers. 


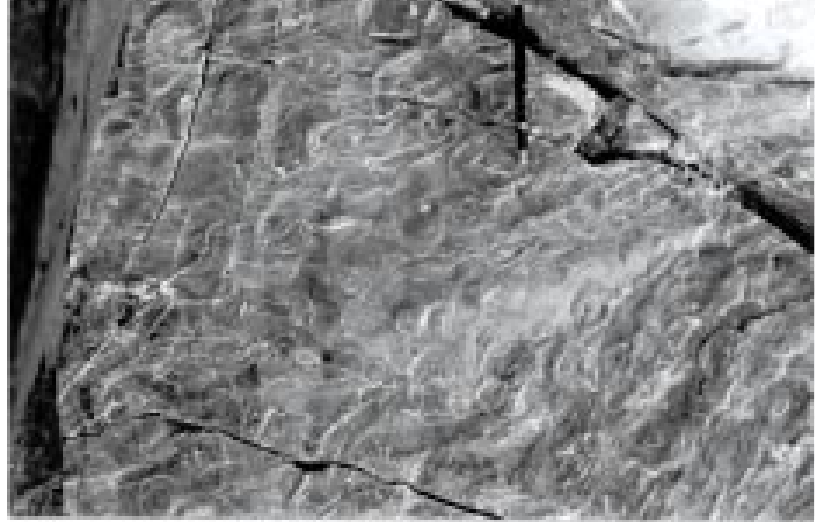

Photo 3. Stromatolites in dolomitic marbles.
The thin upper unit is formed by orthoquartzites and fine- to medium-grained sandstones, interbedded with sericite phyllites, graphite phyllites, psammitic-pelitic metarhythmites, metasiltites and meta-argillites. Horizontal lamination, normal micro-scale gradational bedding and lowangle cross lamination are preserved.

The $S_{1}$ foliation is almost parallel to the bedding $S_{o}$, and is defined by orientation of sericite, chlorite and, very rare biotite. $\mathrm{S}_{1}$ is affected by heterogeneous crenulation (Table 2; Figure 2). This structural pattern is different from that seen in the Açungui basin (Ribeirão Branco, Guapiara, Rio Ribeira and Bocaiuva Compartiments, Figure 1), where deformation is controlled by low- and high-angle shear zones, and transport is southwards.

Table 2. Deformation phases related with structural features.

\begin{tabular}{cl}
\hline $\begin{array}{c}\text { Observed } \\
\text { Structures }\end{array}$ & \multicolumn{1}{c}{ Features } \\
\hline $\mathrm{S}_{0}$ & $\begin{array}{l}\text { The primary structures, including geopetal structures, amygdales, stromatolites and } \\
\text { algal layer, are well preserved in metarkoses/metavolcanic and metacarbonate } \\
\text { units. The surface's top prevail in a normal position with N40E trend direction } \\
\text { dipping to NW and SE. }\end{array}$ \\
& $\begin{array}{l}\text { A low metamorphic grade, thrust-related foliation is developed parallel to So, and is } \\
\text { well defined by stretched amygdales (photo 2). Associated folds with N40E axial } \\
\text { plane direction are present. } \mathrm{S}_{1} \text { is well defined in metapelitic and metavolcanic rocks } \\
\text { interbedded in meta-arkose. }\end{array}$ \\
$\mathrm{D}_{1}$ & $\begin{array}{l}\mathrm{D}_{2} \text { is defined by open folds, which develop a cleavage } \mathrm{S}_{2} \text { (axial plane) with NE-SW } \\
\text { direction, parallel to the Itaiacoca Belt trend. The } \mathrm{S}_{2} \text { is expressive in metapelitic, } \\
\text { metavolcanic and metarkose rocks, less so in metacarbonatic rocks. (figure 2 and } \\
\text { photo 4) }\end{array}$ \\
\hline $\mathrm{D}_{2}$ &
\end{tabular}

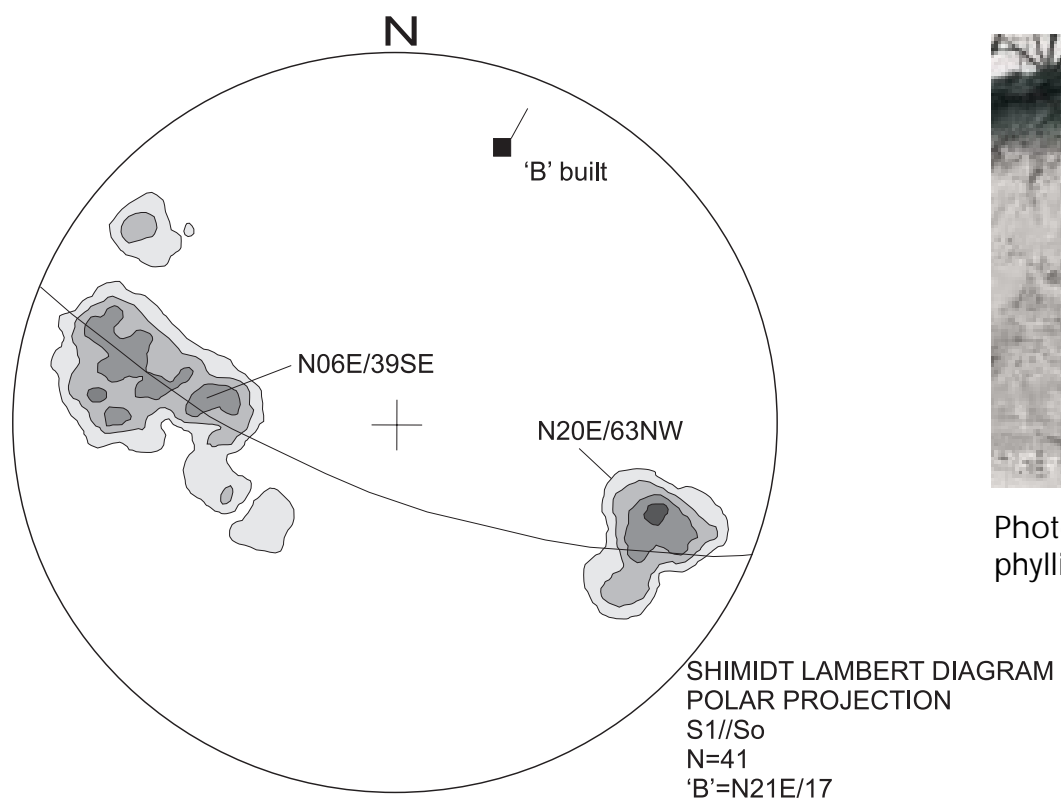

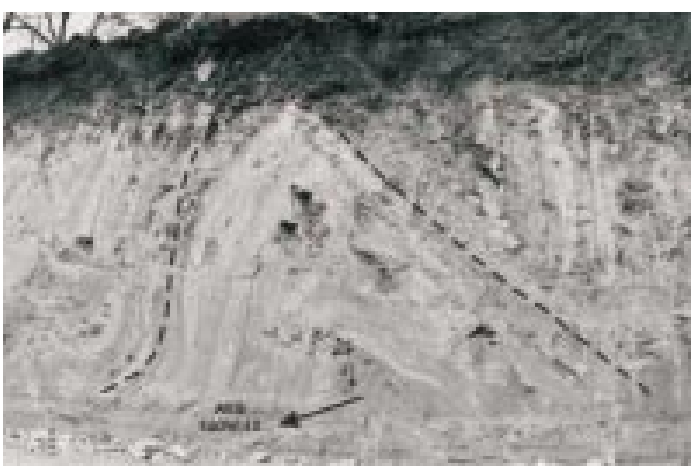

Photo $4 . D_{2}$ fold (axis direction $=\mathrm{S} 60 \mathrm{~W} / 40$ ) in phyllites of Itaiacoca Group, PR.

Figure 2. Stereogram of $D_{2}$ folds standard in metavolcanic rocks (northern portion of Itaiacoca G roup - PR). 


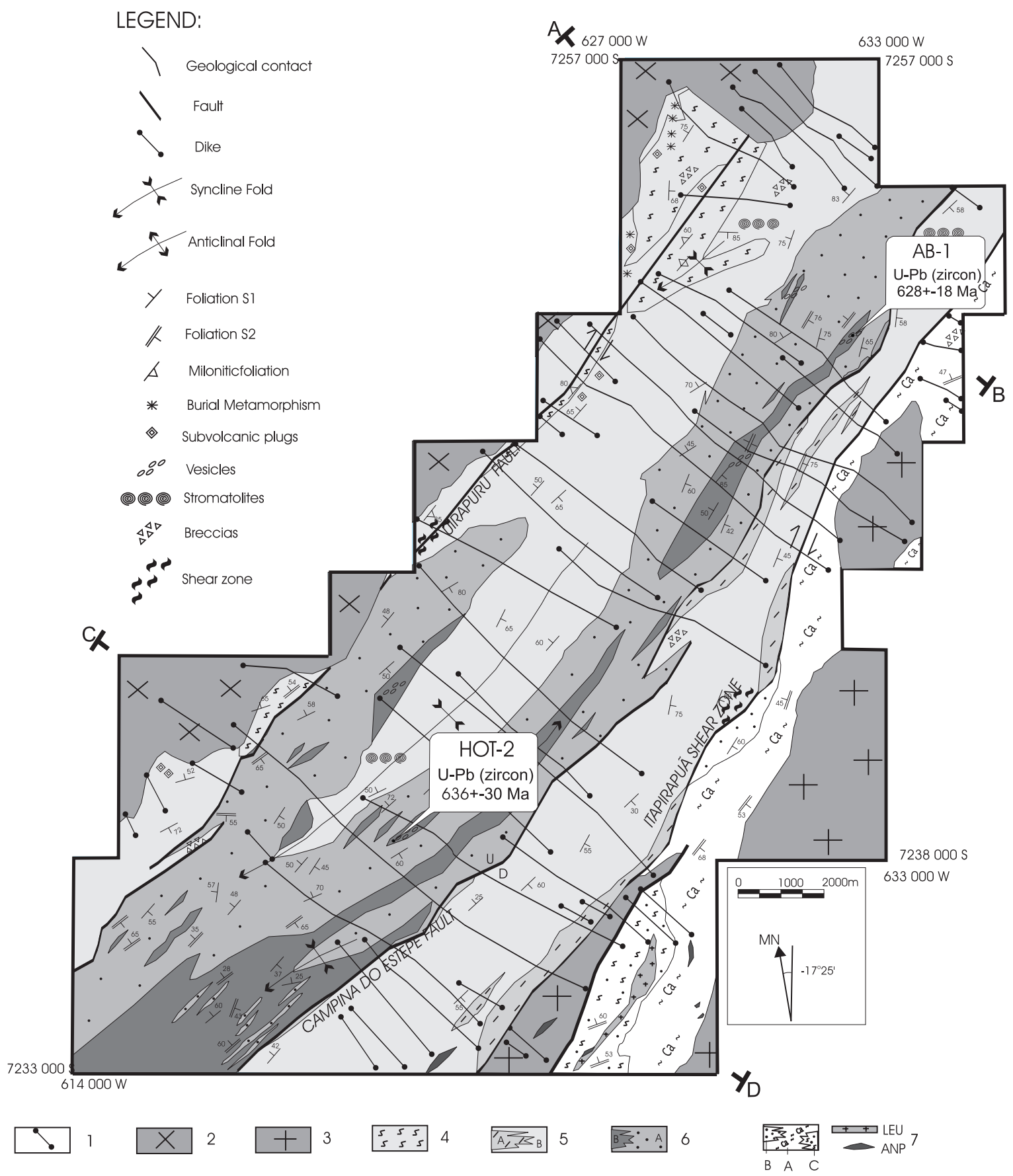

Figure 3. Geological map of Itaiacoca Group, southeastern Paraná (Prazeres Filho et al., 1998; Siga Jr. et al., 2001).

1 - Mesozoic dykes; 2 - Cunhaporanga Granitic Batholith; 3 - Três Córregos Granitic Batholith; Itaiacoca Group (4 a 6): 4 - upper unit - quartz-shists, mica-shists, phyllites, metapelitic rocks with andaluzite; 5 - intermediated unit - A) metamarls, B) stromatolitic metadolomites and metabasic rocks; $\boldsymbol{6}$ - basal unit - A) feldspathic metarenites and metaconglomerates (subordinated), B) interbedded metavolcanic and metavolcanoclastic rocks; 7 - Água Clara Formation: A) Calc-silicate rocks with interbedded leuco syenogranites (Leu) and anphibolites (Anp), B) quartzites, C) muscovite garnet shists. 


\section{GEOLOGICAL CROSS SECTION (A-B and C-D)}

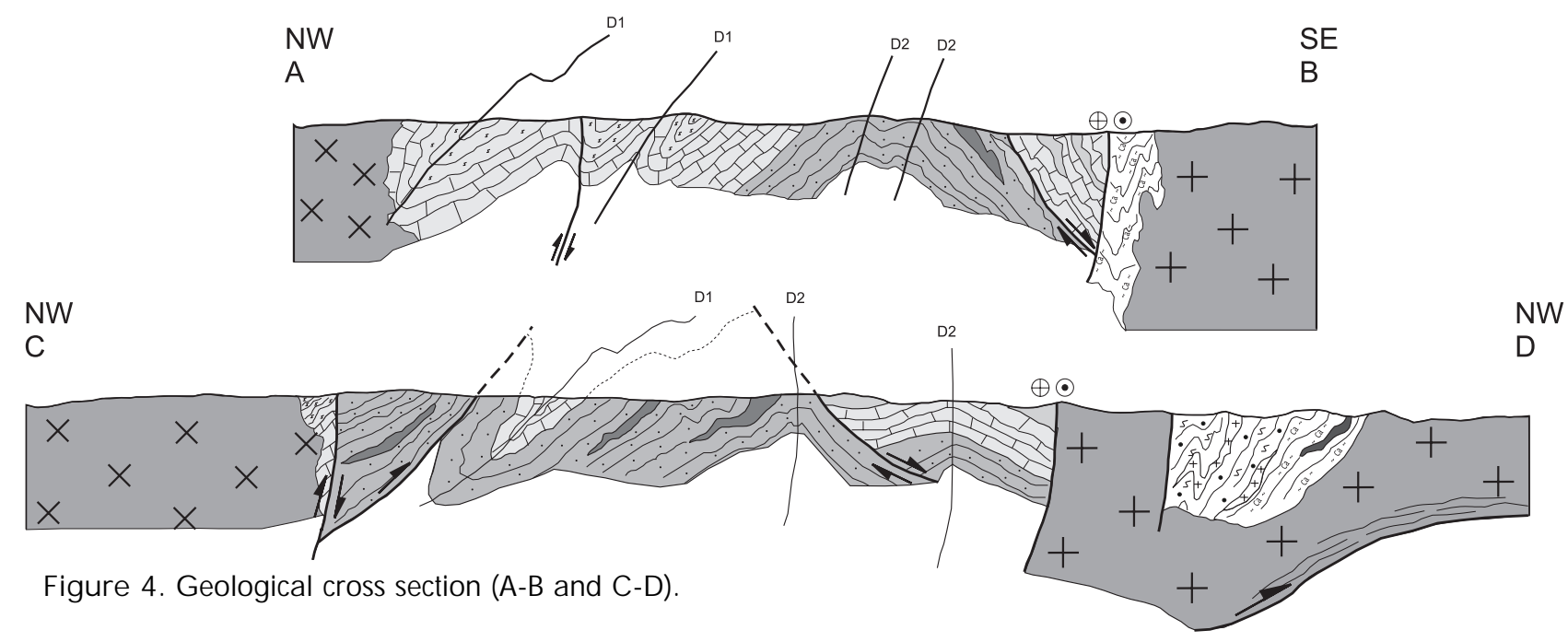

\section{GEOCHRONOLOGICAL STUDIES}

Available geochronological data based on $\mathrm{Pb}-\mathrm{Pb}, \mathrm{Rb}-\mathrm{Sr}$ and $\mathrm{Sm}-\mathrm{Nd}$ measurements in marbles and metavolcanic rocks (Figures 3 and 4) suggest that the age of sedimentation of the Itaiacoca Group is Mesoproterozoic, between 1250 and $1080 \mathrm{Ma}$ (Reis Neto, 1994).

$\mathrm{U}-\mathrm{Pb}$ analyses of zircon grains from metavolcanic rocks interbedded with metawackes collected at points AB-1 and Hot-2 (Figure 3, Table 3) yield ages significantly different from the Mesoproterozoic age preferred by Reis Neto (1994). Zircon grains from AB-1 were analysed by SHRIMP after examination using cathodoluminescence and back-scattered electron images (Research School of Earth Science - Australian National University, Canberra). Weakly tinted, euhedral, long prismatic crystals predominate. They present homogeneously distributed internal growth zones, and cloudy oscillatory zones at the borders. Analyses of points in the homogeneous growth zone, and in the center of the border zone yielded an age of $628 \pm 18 \mathrm{Ma}(\mathrm{MSWD}=1)$ using the Tera-Wasserburg diagram. This age is believed to represent the age of crystallization of the volcanic rocks. Points analysed in the oscillatory border zones of grains of irregular and short prismatic shapes yielded ages of 2480 $\mathrm{Ma}$ and $1990 \mathrm{Ma}$. These ages are thought to represent inherited material from Paleoproterozoic sources (Figure 5).
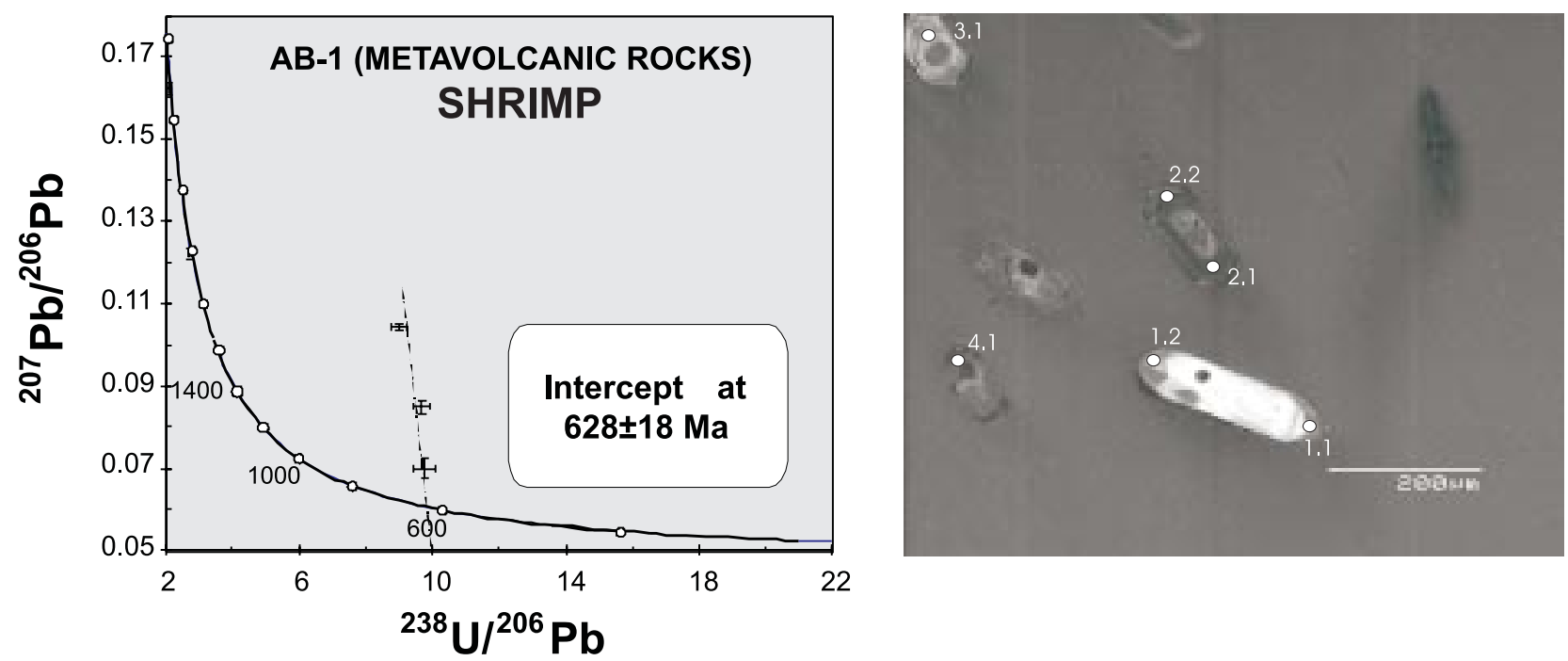

Figure 5. Tera-Wasserburg diagram and cathode-luminescence image of zircon grains from metavolcanic rocks at point AB1 in the Itaiacoca Group (PR). 
Zircon grains from point Hot-2 are colourless, inclusionrich long prisms. The analytical points for three magnetic fractions fall close to the concordia, and define an upper intercept (crystallization) age of $636 \pm 30 \mathrm{Ma}$ (Figure 6), similar to that obtained for $\mathrm{AB}-01$ point.
Although these Neoproterozoic ages must be considered as preliminary, nevertheless they represent the volcanic rocks formation time.
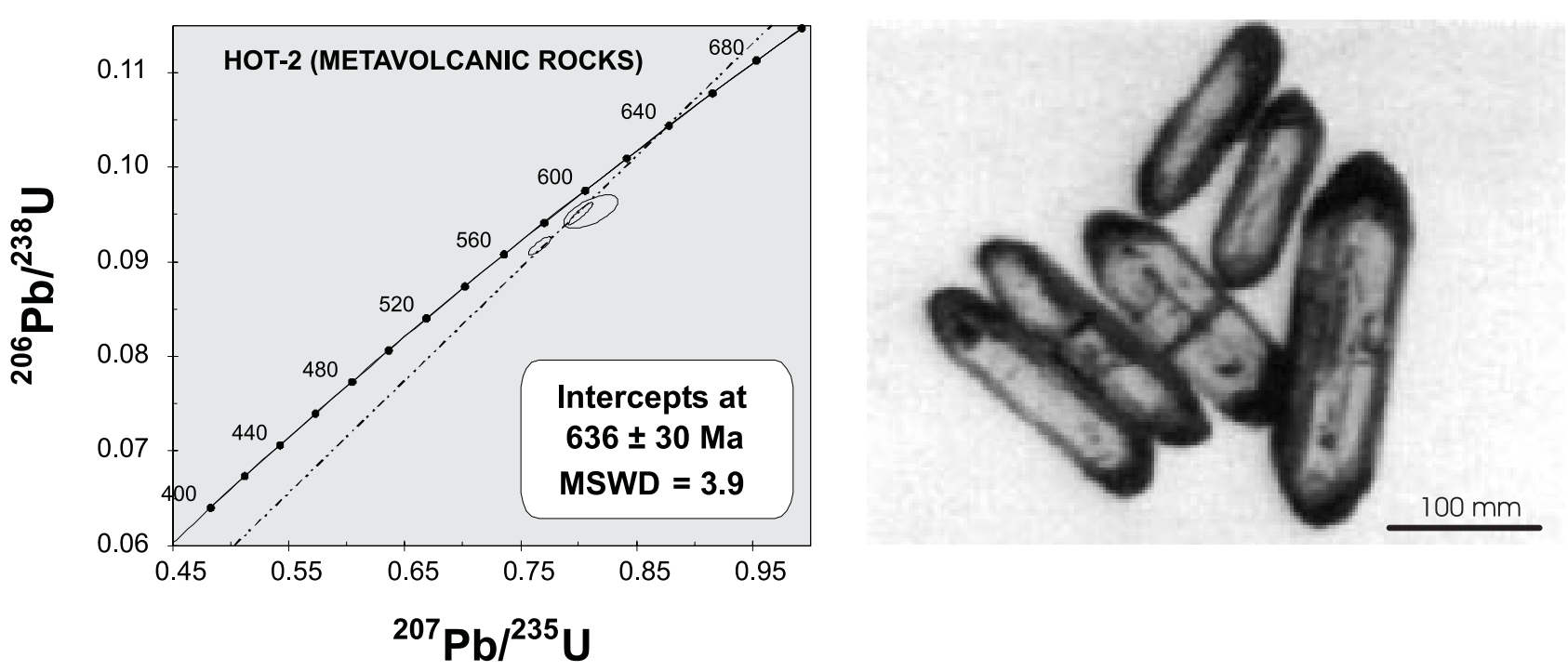

Figure 6. Concordia diagram and transmitted light photograph of zircon grains $(215 \mathrm{x})$ from metavolcanic rocks at point Hot 2 in the Itaiacoca Group (PR).

Table 3. Data for SHRIMP and conventional U-Pb zircon grain analyses.

\begin{tabular}{|c|c|c|c|c|c|c|c|c|c|c|c|c|c|c|}
\hline \multicolumn{15}{|c|}{ AB-01 SHIRIMP U/Pb ZIRCON ANALYSIS } \\
\hline Labels & $\begin{array}{c}\text { Grain } \\
\text { type }\end{array}$ & Uppm & Thppm & Th/U & ${ }^{206} \mathrm{~Pb} \%$ & \multicolumn{2}{|c|}{ Ratio ${ }^{238} \mathrm{U} /{ }^{206} \mathrm{~Pb}$} & \multicolumn{2}{|c|}{ Ratio ${ }^{207} \mathrm{~Pb} /{ }^{206} \mathrm{~Pb}$} & $\begin{array}{c}\text { Date } \\
\operatorname{Ma\pm 1\delta }\end{array}$ & $\begin{array}{c}\% \\
\text { disc }\end{array}$ & \multicolumn{3}{|c|}{$\begin{array}{l}\text { 207-corr. } \\
(206 / 238)\end{array}$} \\
\hline 1.1 & e,osc,rex,p & 35 & 40 & 1.12 & $1.33 \pm 0.29$ & \multicolumn{2}{|l|}{$9.777 \pm 0.330$} & \multicolumn{2}{|c|}{$0.0700 \pm 0.0024$} & $620 \pm 20$ & & \multicolumn{3}{|c|}{$620 \pm 20$} \\
\hline 1.2 & og,hd,p & 126 & 69 & 0.55 & $3.15 \pm 0.20$ & \multicolumn{2}{|l|}{$9.678 \pm 0.261$} & \multicolumn{2}{|c|}{$0.0849 \pm 0.0016$} & $615 \pm 16$ & & \multicolumn{3}{|c|}{$615 \pm 16$} \\
\hline 2.1 & e,osc,p & 1301 & 1053 & 0.81 & $9.29 \pm 0.08$ & \multicolumn{2}{|l|}{$13.927 \pm 0.285$} & \multicolumn{2}{|c|}{$0.1352 \pm 0.0007$} & $407 \pm 8$ & & \\
\hline 2.2 & $e, o s c, p$ & 755 & 701 & 0.93 & $5.49 \pm 0.05$ & \multirow{2}{*}{\multicolumn{2}{|c|}{$\begin{array}{l}9.019 \pm 0.206 \\
2094+0.047\end{array}$}} & \multicolumn{2}{|c|}{$0.1041 \pm 0.0004$} & $642 \pm 14$ & & & & \\
\hline 3.1 & e,osc,p & 84 & 151 & 1.80 & $0.57 \pm 0.12$ & & & \multicolumn{2}{|c|}{$0.1622 \pm 0.0014$} & $2479 \pm 14$ & 2 & \multicolumn{3}{|c|}{$642 \pm 14$} \\
\hline 4.1 & e,osc,p & 211 & 329 & 1.56 & $0.41 \pm 0.11$ & \multicolumn{2}{|l|}{$\frac{2.094 \pm 0.04 I}{2.706 \pm 0.063}$} & 0.122 & $3 \pm 0.0012$ & $1990 \pm 18$ & 2 & & & \\
\hline \multicolumn{5}{|c|}{$\begin{array}{l}\text { labels }(x . y)=\text { grain number. analysis number } \\
\text { bold }=\text { used in pooled date }\end{array}$} & \multirow{2}{*}{\multicolumn{7}{|c|}{$\begin{array}{l}\text { grains 1\& 2: uncorrected ratios and } 207 \text { corrected } 206 \mathrm{~Pb} / 238 \mathrm{U} \text { date; } \\
\text { grains } 3 \& 4: \quad 204 \text { corrected ratios and }{ }^{207} \mathrm{~Pb} /{ }^{206} \mathrm{~Pb} \text { date corrected with model } \mathrm{Pb} \text { of } \\
\text { Cumming and Richards (1975) for likely age of rock } \\
\text { all errors are } 1 \delta\end{array}$}} & \multirow{2}{*}{\multicolumn{3}{|c|}{$\begin{array}{c}628 \pm 18 \\
m s w d=1.0\end{array}$}} \\
\hline \multicolumn{5}{|c|}{$\begin{array}{l}\text { grain type legend: } \\
\mathbf{p}=\text { prism; } \mathbf{e}=\text { end on edge; } \\
\text { og = overgrow; } \mathbf{c}=\text { core; rex = recrystallised; } \\
\text { osc = oscillatory finescale zoning; } \\
\mathbf{h}=\text { homogeneous ( } \mathbf{d}=\text { dark or } \mathbf{b}=\text { bright) }\end{array}$} & & & & & & & & & & \\
\hline \multicolumn{15}{|c|}{ HOT-02 CONVENTIONAL U/Pb ZIRCON ANALYSIS } \\
\hline $\begin{array}{c}\text { Sample } \\
\text { (SPU) }\end{array}$ & $\begin{array}{c}\text { Grain } \\
\text { type }\end{array}$ & ${ }^{207} \mathrm{~Pb} /{ }^{235} \mathrm{U}$ & Er. & ${ }^{206} \mathrm{~Pb} /{ }^{238} \mathrm{U}$ & Er. & Coeff. & & ${ }^{204} \mathrm{~Pb}$ & $\mathrm{~Pb}(\mathrm{ppm})$ & $\mathrm{U}(\mathrm{ppm})$ & Weigth & $\begin{array}{l}\text { 206/238 } \\
\text { Age(Ma) }\end{array}$ & $\begin{array}{l}\text { 207/235 } \\
\text { Age(Ma) }\end{array}$ & $\begin{array}{l}\text { 207/206 } \\
\text { Age(Ma) }\end{array}$ \\
\hline 755 & $\mathrm{p}, \mathrm{bt}, \mathrm{cl}$ & 0.921362 & \pm 1.71 & 0.098227 & \pm 1.3 & 0.7697 & 162 & & 44.93 & 317.8 & 35.79 & 604 & 663 & 869 \\
\hline 756 & pbt,inc & 0.801021 & \pm 1.07 & 0.095156 & \pm 0.988 & 0.9229 & 137 & & 39.87 & 395.9 & 76.17 & 586 & 597 & 641 \\
\hline 758 & $\mathrm{p}, \mathrm{bt}, \mathrm{cl}$ & 0.8423 & \pm 1.15 & 0.096217 & \pm 0.993 & 0.8663 & 137 & & 35.44 & 345.5 & 120.32 & 592 & 620 & 725 \\
\hline 757 & Ip,inc & 0.765822 & \pm 1.06 & 0.091754 & \pm 0.891 & 0.8472 & & & 25.83 & 270.2 & 52.35 & 566 & 577 & 623 \\
\hline
\end{tabular}

grain type legend: $\mathbf{p}=$ prism; $\mathbf{b t}=$ bi-terminated; $\mathbf{c l}=$ clear; $\mathbf{i n c}=$ with inclusions. 


\section{FINAL REMARKS}

When the conventional and SHRIMP zircon ages of the metavolcanic rocks intercalated in the basal metapsammites of the Itaiacoca Group are considered together with the lithostratigraphic sequence, the structural pattern and the tectonic position of the Group, the following observations can be made:

1. the rocks of Itaiacoca Group are pinched between the Cunhaporanga (NW) and Três Córregos (SE) granitic batholiths, which are thought to be parts of Neoproterozoic (630 - 590 Ma) magmatic arcs (Prazeres Filho, 2000);

2. the Três Córregos batholith is slightly older than the Cunhaporanga batholith, and the latter caused contact metamorphism in the Itaiacoca Group;

3. the basal unit of the Itaiacoca Group contains an important alkaline metavolcanic component, interbedded with metapsammites containing quartz and K-feldspar clasts suggestive of a granitic source region;

4. the geochronological data reported here show that the metavolcanic rocks were erupted at about 635-630 Ma;

5. the age of sedimentation of Itaiacoca Basin seems to lie near the Mesoproterozoic/Neoproterozoic limit according to Reis Neto (1994). This author suggests ages of about $1250-1080 \mathrm{Ma}(\mathrm{Rb}-\mathrm{Sr}, \mathrm{Pb}-\mathrm{Pb})$ for metabasic rocks and marbles of upper unit of Itaiacoca Group (Bairro dos Campos Formation);

6. the $S_{1}$ foliation, parallel to the compositional banding, contains sericite, chlorite and rare biotite, and is heterogeneously crenulated;

7. unpublished $\mathrm{K}-\mathrm{Ar}$ analyses of neoformed fine-grained $(<2 \mu \mathrm{m})$ sericites from phyllites and metavolcanic rocks showed that the metamorphism ocurred between 628 and $610 \mathrm{Ma}$ (Basei, verbal communication).

The U-Pb (zircon) ages from metavolcanic rocks of the Itaiacoca Group (635 - 630 Ma) constitute an important geochronological bench mark in the evolution of this basin, once they should represent 'minimum ages' of Itaiacoca's sedimentation.

These ages are quite close to the metamorphic event recorded in the Itaiacoca Group (628 - 610 Ma), suggesting an interval between the formation of this rocks and closure of the basin. Furthermore, this volcanism is very close to the age of formation of Três Córregos and Cunhaporanga granitic batholiths, admitted as associated with a probable magmatic arc (Prazeres Filho, 2000) with ages between 630 Ma (Três Córregos Batholith) and $590 \mathrm{Ma}$ (Cunhaporanga Batholith).
Such an isotopic pattern characterizes a Neoproterozoic tectonic scenario involving volcanism, metamorphism and granitic plutonism, interpreted here as the final stages in the evolution of the Itaiacoca Basin.

In addition, isotopic studies on metabasic rocks (upper unit) as well detritic zircons have been carried out in the Itaiacoca Group rocks, which provide a better understanding of the evolution of Itaiacoca Basin.

\section{ACKN O WLEDG EMEN TS}

The authors acknowledge the support from FAPESP (contract no. 99/04040-8) which permitted this study to be undertaken and to Prof. Dr. Ian McReath for suggestions and a critical review of the manuscript.

\section{REFEREN CES}

ALMEIDA, F.F.M. 1956. Novas ocorrências de fósseis no Pré-Cambriano brasileiro. In: Academia Brasileira de Ciências, Rio de Janeiro, Anais, 28:44-45.

BASEI, M.A.S.; SIGA JR., O.; MACHIAVELLI, A.; MANCINI, F. 1992. Evolução tectônica entre dos terrenos entre os Cinturões Ribeira e Dom Feliciano (PR-SC). Rev. Bras. Geoc., 22(2): 216-221.

BASEI, M.A.S.; SIGA JR, O; KAULFUSS, G.A.; CORDEIRO, H.; NUTMAN, A.; SATO, K.; CURY, L.F.; PRAZERES FILHO, H.J.; PASSARELLI, C.R.; HARARA, O.M.M.; REIS NETO, J.M. 2002. Magmatismo básico Mesoproterozóico no Vale do Ribeira - Implicações na idade de deposição das sequencias metavulcanosedimentares Perau e Votuverava, Estado do Paraná, Brasil. Revista do IGc-USP, Série Científica (no prelo).

BIGARELLA, J.J. \& SALAMUNI, R. 1956. Estudos preliminares na Série Açungui VII: algumas estruturas singenéticas nos dolomitos da Formação Capiru. Arq. Biol. Tecn., Curitiba, 11-197EBERT, H. 1971. Observações sobre a litologia e subdivisão do "Grupo Setuva" no Estado do Paraná: com sugestões à tectônica geral do "Geossinclíneo Açungui". In.: SBG, Congresso Brasileiro de Geologia, 25, São Paulo, Anais, 1:131-146.

BIONDI, J. C. (Coord.). 1989. Mapa geológico do Estado do Paraná; esc.: 1:650.000. MINEROPAR, Convênio DNPM/ Sec. Ciência e Tecnol. e Desen. Econ. do Estado do Paraná, Curitiba.

CAMPANHA, G.A.; BISTRICHI,C.A.; ALMEIDA, M.A. 1987. Considerações sobre a organização litoestratigráfica e evolução tectônica da Faixa de Dobramentos 
Apiaí. In: SIMP. SUL-BRAS. GEOL., 3. Atas... Curitiba, SBG., v. 2, p. 725-742.

CAMPANHA, G.A.C. 1991 Tectônica proterozóica do Alto e Médio Vale do Ribeira, estados de São Paulo e Paraná. Tese de Doutoramento. IG-USP, São Paulo, 296pp.

CAMPANHA, G. A. C.; SADOWSKI, G. R. - 1999-Tectonics of southern portion of the Ribeira Belt (Apiaí Domain). Precambrian Research 98 (1999) 31-51.

CAMPOS NETO, M. C. (2000). Orogenic Systems from Southwestern Gondwana: na approach to Brasiliano-Pan African cycle and orogenic collage in southeastern Brazil. In: CORDANI, U.G.; MILANI, E.J.; THOMAS FILHO, A.; CAMPOS, D.A.. Tectonic Evolution of South America, Rio de Janeiro, 2000, p: 335-365.

CURY, L.F; KAULFUSS, G.A.; SIGAJR, O.; BASEI, M.A.S.; SATO, K.; HARARA, O.M.M. 2002. Idades U-Pb (Zircões) de 1.75 ga em granitóides alcalinos deformados dos núcleos Betara e Tigre: evidências de regimes extensionais do Estateriano na Faixa Apiaí. Revista do IGc-USP, Série Científica (no prelo).

CHIODI FILHO, C. 1984. Contribuição a geologia das regiões sul paulista e leste paranaense, grupos Açungui e Setuva. In.: CONGRESSOBRASILEIRODEGEOLOGIA, 33, Rio de Janeiro, 1984. Atas... Rio de Janeiro : SBG, 1984, v. 5, p. 2394-2406.

FASSBINDER, E. 1996. A unidade Água Clara no contexto do Grupo Açungui: um modelo transpressivo de colisão oblíqua no Neoproterozóico paranaense. Inst. de Geociências, Universidade de São Paulo, São Paulo, Tese de Doutoramento, 207p.

FAIRCHILD, T.R. 1977 - Comophyton and other columnar stromatolites from the upper Precambrian Açungui Group near Itapeva, São Paulo, Brazil. In: Simp. Reg. Geol., 1, São Paulo, 1977. Atas...SBG. p. 179-198.

FIORI, A.P. 1990. Tectônica e Estratigrafia do Grupo Açungui a Norte de Curitiba. São Paulo. 261 p. (Tese de Livre Docência, Instituto de Geociências da Universidade de São Paulo).

FIORI, A.P. 1992. Tectônica e estratigrafia do Grupo Açungui, PR. Boletim IG-USP, Série Científica, 23:55-74.

FUCK, R.A.; MARINI, O.J.; TREIN, E. 1967. Contribuição ao estudo ao estudo das rochas graníticas do Estado do Paraná. Boletim Paranaense de Geociências, 23-25:183-221.

FUCK, R.A.; MARINI, O.J.; TREIN, E.; MURATORI,A. 1971. Geologia do leste Paranaense. In: SBG, Congresso Brasileiro de Geologia, 25, Rio de Janeiro, Anais, 5:121-130.
HASUI, Y.; CARNEIRO, C.D.R.; COIMBRA, A.M. 1975. The Ribeira Folded Belt. Revista Brasileira de Geociências, 5: 257-266.

HASUI, Y.; CREMONINI, O.A.; BORN, H. 1984. Considerações sobre o Grupo Açungui em São Paulo e porção adjacente no Paraná. In: 33CBG, Rio de Janeiro. Anais...Rio de Janeiro, SBG, v.7, p.3297-3306.

IPT (INSTITUTO DE PESQUISAS TECNOLÓGICAS DO ESTADO DE SÃO PAULO). 1985. Geologia das Folhas Barra do Chapéu (SG-22-X-B-I-4) e Araçaíba (SG-22-XB-II-3), estados de São Paulo e Paraná. São Paulo, IPT (relatório 22150).

MARINI, O.J.; TREIN; E.; FUCK, R.A. 1967. O Grupo Açungui no estado do Paraná. In: Bigarella, J.J.; Salamuni, R.; Pinto, V.M. Geologia do Pré-Devoniano e Intrusivas Subseqüentes da porção oriental do Estado do Paraná, Curitiba, UFPR, p-43-104 (Boletim 23/25).

PRAZERES FILHO, H.J.; GUIMARÃES, G.; BASEI, M.A.S.; SIGA JR, O.; REIS NETO, J.M.; CAMPANHA, G.; SALLUN FILHO, W. 1998. Mapa geológico 1:50.000 da porção centro-sul da Faixa Itaiacoca - PR. XL Congres. Brás. Geol., Belo Horizonte, MG, Resumos, pág. 36.

PRAZERES FILHO, H.J. 2000. Litogeoquímica, Geocronologia (U-Pb) e Geologia Isotópica dos Complexos Graníticos Cunhaporanga e Três Córregos, Estado do Paraná. Dissertação de Mestrado - IGc-USP, 180p.

PRAZERES FILHO, H.J.; BASEI, M.A.S.; HARARA, O.M.; PASSARELLI, C.R.; SIGA Jr.,O.; REIS NETO, J.M.; SATO, K. 2001. The Alto Ribeira Magmatic Arc (Paraná StateSouthern Brazil): Geochemical and Isotopic Evidences of Magmatic Focus Migration and Its Tectonic Implications. In: III Simpósio Sul-Americano de Geologia Isotópica, Pucon, Chile. Extend Abstract p.213-216.

REIS NETO, J.M. 1994. Faixa Itaiacoca: registro de uma colisão entre dois blocos continentais no neoproterozóico. Int. de Geociências, Universidade de São Paulo, São Paulo, Tese de Doutoramento, 253p.

SIGA JR., O.; BASEI, M.A.S.; REIS NETO, J.M.; MACHIAVELLI, A.; HARARA, O.M. 1995. O Complexo Atuba: um cinturão Paleoproterozóico intensamente retrabalhado no Neoproterozóico. Boletim IG-USP, Série Científica, 26: 69-98.

SIGA JR, O.; BASEI, M.A.S.; WEBER, W.; SATO, K.; REIS NETO, J.M.; PRAZERES FILHO, H.J.; NUTMAN, A.P. 2001. The Itaiacoca Group: U-Pb (zircon) records of a Neoproterozoic Basin: III South American Symposium on Isotope. Pucón - Chile.

SOARES, P. C. 1987. Seqüências tectono-sedimentares e tectônica deformadora no centro-oeste do Escudo 
Paranaense. In: SBG, Simpósio Sul Brasileiro de Geologia, 3, Curitiba, Atas, 1:245-258.

SOARES, P. C.; ROSTIROLLA, S.P. 1997. Tectônica de escape tardicolisional nos Cinturões Ribeira e Dom Feliciano. In: SBG, Simpósio Nacional de Estudos Tectônicos, 6, Pirinópolis, Anais,.65-68.

SOUZA, A. P. 1990. Mapa Geológico na Esc.: 1:50.000 e esboço de evolução tectônica e sedimentar do Grupo Itaiacoca, nas folhas Barra do Chapéu e Ouro Verde (SP)(PR). Inst. de Geociências, Universidade de São Paulo, São Paulo, dissertação de mestrado, 200p.

THEODOROVIZ, A; CÂMARA, M.M. 1988. Ambiência tectônica da Faixa Itaiacoca na região sudeste do estado de São Paulo. In: $35^{\circ}$. Congresso Brasileiro de Geologia, Belém, SBG Anais, vol.6, p2713-2726.

TREIN, E.; REIS NETO, J.M.; BIONDI, J.C.; MONASTIER, M.S. 1985. Revisão da Formação Itaiacoca: identificação de uma seqüência metavulcanossedimentar em Abapã (PR). In: SBG, Simpósio Regional de Geologia, 5, São Paulo, Atas, 1:169-186.

WEBER, W.; SIGAJUNIOR, O.; SATO, K; REIS NETO, J.M.; BASEI, M.A.S.; NUTTMAN, A. 2002. AFormação Água Clara na região de Araçaiba-SP: Registro U-Pb de uma bacia Mesoproterozóica. Revista do IGc-USP, Série Científica (no prelo). 